\title{
Polymorphic microsatellite loci from the endangered Giant Otter (Pteronura brasiliensis)
}

\author{
Carolina Ribas • Anderson V. Vasconcellos • \\ Guilherme Mourão • William Magnusson • \\ Antonio M. Solé-Cava $\cdot$ Haydée A. Cunha
}

Received: 4 May 2011/ Accepted: 5 May 2011/Published online: 22 May 2011

(C) Springer Science+Business Media B.V. 2011

\begin{abstract}
We describe the first microsatellite loci isolated from the giant otter (Pteronura brasiliensis), an endangered mustelid endemic to South America. Fourteen di- and trinucleotide polymorphic loci were characterised in fourteen individuals from the Pantanal wetlands, Central Brazil. Number of alleles per locus ranged from 2 to 5 , and average observed heterozygosity was 0.577 . Two loci were in linkage disequilibrium, and one further locus deviated from Hardy-Weinberg equilibrium, probably due to the presence of null alleles. The transferability of these markers to two other mustelids (Lontra longicaudis and Eira barbara) and to the mephitid Conepatus semistriatus was also evaluated. These loci are useful to study the ecology and evolution of these species.
\end{abstract}

\section{Ribas $(\bowtie)$}

Laboratório de Biodiversidade Molecular, Departamento de Genética, Instituto de Biologia, Universidade Federal do Rio de Janeiro, Prédio do CCS, B1. A, S1. A2-98. Ilha do Fundão, Rio de Janeiro 21941-590, Brazil

e-mail: ariranhapantanal@yahoo.com.br

C. Ribas · A. V. Vasconcellos · A. M. Solé-Cava · H. A. Cunha Laboratório de Biodiversidade Molecular, Departamento de Genética, Instituto de Biologia, Universidade Federal do Rio de Janeiro, Rio de Janeiro 21941-590, Brazil

C. Ribas · G. Mourão

Embrapa Pantanal, Corumbá, Mato Grosso do Sul, Brazil

C. Ribas · W. Magnusson

Coordenação de Pesquisas em Ecologia, Instituto Nacional de

Pesquisas da Amazônia, Manaus, Amazonas, Brazil

H. A. Cunha

Laboratório de Mamíferos Aquáticos e Bioindicadores (MAQUA), Faculdade de Oceanografia, Universidade do Estado do Rio de Janeiro, Rio de Janeiro, Brazil
Keywords Lutrinae - Mustelidae $\cdot$ Mephitidae · Kinship $\cdot$ Social system $\cdot$ Population structure

Giant otters (Pteronura brasiliensis) are large semi-aquatic mustelids (sub-family Lutrinae) and one of the few social carnivores endemic to South America. They are considered the most threatened otter species in the world (IUCN 2010) as a consequence of historical hunting (Carter and Rosas 1997), and past and present anthropogenic habitat destruction (e.g. mining and hydroelectric dams, river and land pollution, and over-fishing) (Schenck 1999; OSG IUCN 2010).

Microsatellites are ideal markers to address population structure and kinship issues, thus they are able to provide crucial information for the elaboration of conservation plans for this endangered species. Although microsatellite primers developed for Eurasian and North American River otters (Lutra lutra and Lontra canadensis, respectively) have been tested in giant otters (Pickles et al. 2009), the use of heterologous primers may lead to underestimation of heterozygosity ("ascertainment bias", Garner et al. 2005). Therefore, we isolated microsatellite loci for P. brasiliensis (which are the first microsatellites characterised in otters from Latin America). We also tested their applicability in the mustelids Lontra longicaudis (neotropical river otter) and Eira barbara (tayra), and in the mephitid Conepatus semistriatus (striped hog-nosed skunk).

Genomic DNA was extracted from giant otter skin samples collected with biopsy darts (Ribas et al. in prep.), using a phenol-chloroform protocol (Sambrook et al. 1989). Microsatellites were isolated from an enriched partial genomic library, following the protocol of Bloor et al. (2001). A pool of high-quality genomic DNA $(4 \mu \mathrm{g})$ was digested with SauIIIA, ligated to phosphorylated double-stranded linker 
oligonucleotides and size selected (between 500 and $1000 \mathrm{bp}$ ). DNA fragments were hybridised with biotinylated $(\mathrm{CA})_{12},(\mathrm{CAA})_{8}$ and $(\mathrm{GATA})_{5}$ probes, and isolated using streptavidin-coated magnetic beads. The forward linker oligo was used as a primer for enrichment of DNA containing microsatellites. Enriched fragments were then cloned using pGEM-T vectors (Promega) and OneShot TOP10 competent cells (Invitrogen). Recombinant clones were screened for the presence of microsatellite inserts, which was confirmed by two or more amplified products after a PCR primed with the forward linker oligo and (non-biotinylated) microsatellite oligos. Forty-eight positive clones were sequenced in both directions in an ABI3500 sequencer. Sequences were edited using SeqMan (DNAStar).
Twenty-five primer pairs flanking microsatellite regions were designed using WebSat (Martins et al. 2009). We used the tailed primer method (Schuelke 2000), hence, PCR reactions contained three primers: tailed (forward with M13 tail), labelled (M13 with either VIC, NED, PET or 6-FAM fluorescent dyes), and reverse. PCR consisted of $1 \mathrm{U}$ GoTaq (Promega), $0.20 \mathrm{mM}$ dNTPs, $2.5 \mathrm{mM} \mathrm{MgCl}{ }_{2}$, $15 \mu \mathrm{g}$ BSA, $0.2 \mu \mathrm{M}$ of tailed primer, $0.4 \mu \mathrm{M}$ of labelled primer, and $0.8 \mu \mathrm{M}$ of reverse primer, in $15 \mu \mathrm{l}$ reactions with approximately $20 \mathrm{ng}$ of DNA template. Cycling conditions were: $94^{\circ} \mathrm{C}, 4 \mathrm{~min}, 30 \mathrm{X}\left(92^{\circ} \mathrm{C}, 45 \mathrm{seg} ; \mathrm{T}_{\mathrm{a}}, 45\right.$ seg; $\left.72^{\circ} \mathrm{C}, 45 \mathrm{seg}\right), 8 \mathrm{X}\left(92^{\circ} \mathrm{C}, 45 \mathrm{seg} ; 53^{\circ} \mathrm{C}, 45 \mathrm{seg} ; 72^{\circ} \mathrm{C}\right.$, $45 \mathrm{seg}), 72^{\circ} \mathrm{C}, 30 \mathrm{~min} . \mathrm{T}_{\mathrm{a}}$ for all primer pairs was $60^{\circ} \mathrm{C}$, except for $\mathrm{Pbra01}$, which was $52^{\circ} \mathrm{C}$. PCR products were

Table 1 Levels of variability of 14 polymorphic microsatellite loci in the giant otter (Pteronura brasiliensis) from Pantanal, Brazil $(n=14)$

\begin{tabular}{|c|c|c|c|c|c|c|c|c|c|}
\hline Locus & $\begin{array}{l}\text { GenBank } \\
\text { accession no. }\end{array}$ & Primer sequence $\left(5^{\prime}-3^{\prime}\right)$ & Motif & $\begin{array}{l}\text { Size range }{ }^{a} \\
\text { (bp) }\end{array}$ & $\mathrm{N}_{\mathrm{a}}$ & $\begin{array}{l}\mathrm{H}_{\mathrm{o}} \\
\mathrm{H}_{\mathrm{e}}\end{array}$ & $\begin{array}{l}\text { Null } \\
\text { freq. }\end{array}$ & PExcl1 & PExcl2 \\
\hline Pbra01 & JF712852 & $\begin{array}{l}\text { F: ACCACAAGGGGTTCACTCTAAA } \\
\text { R: TGACCTACTGTCCATTCTGCTG }\end{array}$ & $\mathrm{AC}(18)$ & $219-225$ & 4 & $\begin{array}{l}0.357 \\
0.521\end{array}$ & 0.1875 & 0.871 & 0.749 \\
\hline Pbra02 & JF712853 & $\begin{array}{l}\text { F: TCTCCCCATTTTCACTCTGG } \\
\text { R: ACTTTCAGCCTTTGGTGCTC }\end{array}$ & $\mathrm{AC}(9) \_\mathrm{AC}(16)$ & $401-413$ & 5 & $\begin{array}{l}0.714 \\
0.746\end{array}$ & 0.0034 & 0.687 & 0.509 \\
\hline Pbra05 & JF712854 & $\begin{array}{l}\text { F: GGAAAGGGTTGCTGAATGAA } \\
\text { R: GAGGGTCCTGATGATGGAAG }\end{array}$ & CA(18) & $363-375$ & 4 & $\begin{array}{l}0.714 \\
0.706\end{array}$ & -0.0159 & 0.743 & 0.578 \\
\hline Pbra08 & JF712855 & $\begin{array}{l}\text { F: TACTCTTTTCAGATGCCCCACT } \\
\text { R: AATATGATGTCTCCCGCACG }\end{array}$ & GT(16) & $181-191$ & 3 & $\begin{array}{l}0.571 \\
0.582\end{array}$ & -0.0051 & 0.843 & 0.734 \\
\hline Pbra09 & JF712856 & $\begin{array}{l}\text { F: CACCTTTCCCTCACTTTTGC } \\
\text { R: TCATCCTTCAGTTATGCCGA }\end{array}$ & $\mathrm{CA}(20)$ & $394-400$ & 3 & $\begin{array}{l}0.429 \\
0.466\end{array}$ & 0.0769 & 0.899 & 0.763 \\
\hline Pbra10 & JF712857 & $\begin{array}{l}\text { F: GCCTGACAAGTGATTGCGTA } \\
\text { R: CCGAACCAGAGGCATAAGAA }\end{array}$ & TG(14) & $319-327$ & 3 & $\begin{array}{l}0.500 \\
0.415\end{array}$ & -0.1328 & 0.92 & 0.798 \\
\hline Pbra11 & JF712858 & $\begin{array}{l}\text { F: GGTTGCCTATGGCTGAGAGA } \\
\text { R: GGAGCATGTCTTCCGTGATT }\end{array}$ & $(\mathrm{TG})(\mathrm{GA})$ & $339-343$ & 3 & $\begin{array}{l}0.714 \\
0.603\end{array}$ & -0.1355 & 0.831 & 0.685 \\
\hline Pbra14 & JF712859 & $\begin{array}{l}\text { F: AGAAACACACACGGGACACA } \\
\text { R: TTGCTAATGCTGTAGGGGCT }\end{array}$ & $\mathrm{AC}(10) \mathrm{CA}(11)$ & $136-160$ & 3 & $\begin{array}{l}0.500 \\
0.405\end{array}$ & -0.1366 & 0.924 & 0.818 \\
\hline Pbra16 & JF712860 & $\begin{array}{l}\text { F: CAGTGCGGGTCATACAAAGA } \\
\text { R: ACAGAACCAGTCCCTGTTGG }\end{array}$ & CTT(8) & $327-336$ & 2 & $\begin{array}{l}0 \\
0.138\end{array}$ & 0.8315 & 0.991 & 0.938 \\
\hline Pbra17 & JF712861 & $\begin{array}{l}\text { F: AACACCAAAGCAAACCCTTG } \\
\text { R: CCACCACAGAAAGCACAAAA }\end{array}$ & TG & $336-350$ & 4 & $\begin{array}{l}0.643 \\
0.775\end{array}$ & 0.0757 & 0.675 & 0.499 \\
\hline Pbra20 & JF712862 & $\begin{array}{l}\text { F: GCCAGACCATCCAACAAAGT } \\
\text { R: TTTCCTTTCTCCATCCTCCA }\end{array}$ & $\mathrm{CA}$ & $358-370$ & 4 & $\begin{array}{l}0.714 \\
0.749\end{array}$ & 0.0144 & 0.701 & 0.526 \\
\hline Pbra21 ${ }^{\mathrm{b}}$ & JF712863 & $\begin{array}{l}\text { F: GGAAACAACACAGCGGAACT } \\
\text { R: CTGAATGAGACACGCAGGAA }\end{array}$ & $\mathrm{AC}(19)$ & $195-205$ & 4 & $\begin{array}{l}0.857 \\
0.759\end{array}$ & -0.078 & 0.693 & 0.520 \\
\hline Pbra $23^{\mathrm{b}}$ & JF712864 & $\begin{array}{l}\text { F: AGATGTTCAGAGAGGCGGAA } \\
\text { R: GGGTGAGTTGTCGGTTTGTT }\end{array}$ & $\mathrm{TG}(17)$ & $171-181$ & 4 & $\begin{array}{l}0.857 \\
0.765\end{array}$ & -0.0735 & 0.686 & 0.512 \\
\hline Pbra24 & JF712865 & $\begin{array}{l}\text { F: GGTGTCTTTGAAGTGGTTAT } \\
\text { R: AGTGGCTTAACGGACTGAGC }\end{array}$ & TG(13) & $313-335$ & 4 & $\begin{array}{l}0.786 \\
0.706\end{array}$ & -0.072 & 0.743 & 0.578 \\
\hline
\end{tabular}

a Allele sizes discounting the tailed extension of the primers

b Linked loci

$N_{a}$ indicates number of alleles observed, $H_{\mathrm{o}}$ observed heterozygosity, $H_{\mathrm{e}}$ expected heterozygosity, Null freq estimated null allele frequency, PExcll and 2 probability of non-exclusion of a parent, unknowing both or one of them, respectively, Bold heterozygote defficiency 
Table 2 Results of cross-amplification tests

\begin{tabular}{|c|c|c|c|c|c|c|c|c|c|c|}
\hline Species & $\mathrm{N}$ & Pbra02 & Pbra05 & Pbra08 & Pbra09 & Pbral1 & Pbral4 & Pbral6 & Pbra17 & Pbra21 \\
\hline Lontra longicaudis & 2 & 60 & 54 & - & 60 & 60 & 58 & 58 & 60 & 52 \\
\hline Eira barbara & 2 & - & 54 & 54 & 58 & 60 & 60 & 58 & 54 & 52 \\
\hline Conepatus semistriatus & 1 & - & - & - & - & - & - & - & - & 56 \\
\hline
\end{tabular}

Failure of amplification is indicated by a minus. Loci that were successfully amplified are indicated by the corresponding annealing temperature $\left({ }^{\circ} \mathrm{C}\right)$

pooled, separated in an ABI3500 sequencer and sized using GeneMapper and GS500-LIZ (Applied Biosystems).

During optimisation attempts, five primer pairs were discarded due to PCR failure. The remaining 20 were evaluated for polymorphisms in fourteen giant otters from the Miranda/Vermelho River (UTM- 21 K 502060, 7831592), Pantanal wetlands, Brazil. Six loci were monomorphic, while 14 loci resolved between 2 and 5 alleles and had observed and expected heterozygosities varying between $0-0.857$ and $0.138-0.775$, respectively (Table 1 ). Deviations from Hardy-Weinberg and linkage equilibrium conditions were tested using FSTAT (Goudet 1995) and the online version of Genepop (Raymond and Rousset 1995). Locus Pbral6 presented a clear heterozygote deficiency, possibly caused by the presence of null alleles, as suggested by the high null allele frequency estimated by the software Cervus (Kalinowski et al. 2007). All loci pairs were in linkage equilibrium, except for markers Pbra21 and Pbra23, which were strongly linked $(P<0.00055$, which remains significant after sequential Bonferroni correction-Rice 1989). The probability of non-exclusion of a false parent was estimated for each locus (Table 1) and also combining the twelve selected markers (i.e. excluding Pbral6 and Pbra21). The estimated proportions of type II errors were small $(5.7 \%$ without knowing the parents and $0.4 \%$ knowing one of them), indicating that the selected loci provide sufficient power for paternity analyses in the species.

All 14 markers were tested for cross-amplification in two individuals each of neotropical otter and tayra, and in one striped hog-nosed skunk, using the optimised conditions detailed in Table 2. Five loci could not be amplified in any of these species (Pbra01, Pbra10, Pbra20, Pbra23 and Pbra24), but seven of them were successfully amplified in the two other mustelids (Table 2).

These markers will contribute to elucidate the giant otter social system and population structure, providing information that will be useful in the elaboration of management and conservation plans for this endangered species.

Acknowledgments We thank Federal University of Mato Grosso do Sul for providing logistic support. This study was part of the Ph.D. dissertation of CR (at INPA, Brazil). CNPq granted a scholarship to $\mathrm{CR}$, and a research grant to GM to support the field and some of
Laboratory costs (\# 476939/2008-9). We are indebted to Isac Teixeira de Carvalho for his fieldwork assistance, to Parque Zoológico Municipal Quinzinho de Barros and Programa de Conservação Mamíferos do Cerrado, for providing Lontra longicaudis, Eira barbara and Conepatus semistriatus tissue samples, respectively. We thank Fabiana Lopes Rocha for all her help and contacts. All collections were authorised by the Environment Ministry (IBAMA 12794-4/2012) and the dart projector was imported under International Import Certificate no 5834/DFPC from the Brazilian Government. We are especially grateful to Gabriel Damasceno for his great aim with the biopsy dart projector.

\section{References}

Bloor PA, Barker FS, Watts PC, Noyes HA, Kemp SJ (2001) Microsatellite libraries by enrichment. Protocol available at: http://www.genomics.liv.ac.uk/animal/Protocoll.html

Carter SK, Rosas FCW (1997) Biology and conservation of the giant otter Pteronura brasiliensis. Mamm Rev 27:1-26

Garner A, Rachlow JL, Hicks JF (2005) Patterns of genetic diversity and its loss in mammalian populations. Conserv Biol 19:1215-1221

Goudet J (1995) FSTAT (version 1.2): a computer program for calculating F-statistics. J Hered 86:485-486

IUCN Red List of Threatened Species (2010) http://www.iucnredlist. org/apps/redlist/details/18711/0. Accessed 13 March 2011

Kalinowski ST, Taper ML, Marshall TC (2007) Revising how the computer program CERVUS accommodates genotyping error increases success in paternity assignment. Mol Ecol 16: $1099-1106$

Martins WS, Lucas DCS, Neves KFS, Bertioli DJ (2009) WebSat-A web software for microsatellite marker development. Bioinformation 3:282-283

OSG-IUCN Otter Specialist Group (2010) http://www.otterspecialistgroup. org/Species/Pteronura_brasiliensis.html. Accessed 13 March 2011

Pickles RSA, Groombridge JJ, Zambrana Rojas VDZ, Jordan WC (2009) Cross-species characterisation of polymorphic microsatellite loci in the giant otter (Pteronura brasiliensis). Mol Ecol Res 9:415-417

Raymond M, Rousset F (1995) GENEPOP, Version 1.2. Population genetics software for exact tests and ecumenicisms. J Hered $86: 249$

Rice WR (1989) Analysing tables of statistic tests. Evolution 43: 223-225

Sambrook J, Fritsch EF, Maniatis T (1989) Molecular cloning a laboratory manual. Cold Spring Harbor Laboratory Press, New York

Schenck C (1999) Lobo de Río (Pteronura brasiliensis): Presencia, uso de hábitat y protección en el Perú. Zoological Society of Frankfurt, Germany

Schuelke M (2000) An economic method for the fluorescent labeling of PCR fragments. Nat Biotechnol 18:233-234 